\title{
SPIROMETRIC AND HYGIENIC CRITERIA IN RECOGNITION OF OCCUPATIONAL COPD IN POLAND - A RETROSPECTIVE ANALYSIS OF MEDICAL RECORDS
}

\author{
ANETA KLENIEWSKA ${ }^{1}$, JOLANTA WALUSIAK-SKORUPA ${ }^{1}$, AGNIESZKA LIPIŃSKA-OJRZANOWSKA ${ }^{1}$, \\ KAMILA SZCZEŚSIAK ${ }^{2}$, and MARTA WISZNIEWSKA ${ }^{1}$
}

Nofer Institute of Occupational Medicine, Łódź, Poland

${ }^{1}$ Department of Occupational Diseases and Environmental Health

${ }^{2}$ Department of Projects' Management, Innovation and Implementation

\begin{abstract}
Objectives: Chronic obstructive pulmonary disease (COPD) may be work-related. It has been estimated that $15 \%$ of the population burden of COPD is attributable to occupational exposure. However, in Poland COPD is rarely recognized as an occupational disease. The aim of the study has been to analyze the causes of the low prevalence of work-related COPD in the context of the existing criteria as well as to analyze which part of the assessment - clinical or hygienic one - is responsible for such a low rate of occupational COPD recognitions. Material and Methods: The study group included 150 patients hospitalized with a suspicion of occupational COPD. Each patient underwent a clinical examination, spirometry and reversibility test using bronchodilator. Moreover, hygienic evaluation of work conditions was performed in all the considered cases. Results: In the case of the patients who fulfilled the criteria for COPD diagnosis in accordance with the Global Initiative for Chronic Obstructive Lung Disease (GOLD) occupational origins of the disease, the disease was not recognized because $24.1 \%$ of the individuals did not meet spirometric criteria included in a definition of COPD in the Polish list of occupational diseases, while $27.8 \%$ of the individuals did not fulfill the criterion of a documented exposure to dusts and irritant gases. None of these criteria was fulfilled by $42.6 \%$ of the patients. Conclusions: In our country, both clinical and hygienic criteria result in limitations in recognition of occupational COPD. There is the need to establish new guidelines for the recognition of COPD as a compensable disease in Poland. Int J Occup Med Environ Health 2018;31(2):139-150
\end{abstract}

Key words:

Compensation, Acknowledgement of occupational disease, VGDF, Occupational, COPD,

Chronic obstructive pulmonary disease

\footnotetext{
Funding: the study was conducted in 2011 and 2013 as part of a statutory project of the Nofer Institute of Occupational Medicine, i.e., project IMP 12.3, entitled "Occupational chronic obstructive pulmonary disease - determinants, diagnostics, evaluation of usefulness of the new diagnostic methods," funded with the resources granted by the Ministry of Science and Higher Education. Project manager: Marta Wiszniewska, M.D., Ph.D.

Received: February 8, 2016. Accepted: December 4, 2016.

Corresponding author: A. Kleniewska, Nofer Institute of Occupational Medicine, Department of Occupational Diseases and Environmental Health, św. Teresy 8 , 91-348 Łódź, Poland (e-mail: klen.an@interia.pl).
} 


\section{INTRODUCTION}

Chronic obstructive pulmonary disease (COPD) is a cause of increasing morbidity and mortality in Poland and worldwide [1-3]. According to the Global Initiative for Chronic Obstructive Lung Disease (GOLD) guidelines of 2016, it is a common preventable and treatable disease, which is characterized by an airflow limitation that is usually progressive and associated with an enhanced chronic inflammatory response to noxious particles or gases in the airways and in the lungs [1]. Although cigarette smoking is the most important risk factor for COPD development, about $15 \%$ of COPD could be attributable to workplace exposure [4-6]. Furthermore, combined effects of tobacco smoke and exposure at work on COPD development have been also observed [5].

In Poland COPD may be recognized as an occupational disease. In the currently applicable Regulation of the Council of Ministers of June 30, 2009 [7] on occupational diseases, chronic obstructive pulmonary disease is included in the list of occupational diseases in point 5 . Its definition is described in detail and includes both spirometric and hygienic criteria which allow to recognize occupational etiology of the disease [7]. Nowadays in Poland, COPD is rarely recognized as an occupational disease. What is more, strict hygienic criterion excludes the possibility of COPD recognition for people who worked in the workplace where work environment monitoring was not performed, e.g., farmers.

In the current study, our primary objective has been to analyze the causes of the low prevalence of workrelated COPD in the context of the existing criteria. As a secondary aim, we have tried to determine which part of the assessment - clinical or hygienic one - is responsible for the low rate of occupational COPD. Furthermore, we have analyzed individual patients, in the case of whom despite fulfilling GOLD criteria for COPD, the disease had not been recognized as an occupational case.

\section{MATERIAL AND METHODS}

\section{Study population}

The study population consisted of 150 patients diagnosed with a suspicion of work-related COPD and examined in the Department of Occupational Diseases and Environmental Health, Nofer Institute of Occupational Medicine, Łódź, Poland, between 1998 and 2015. In all cases, medical documentation has been analyzed, with particular emphasis on the type of occupational exposure, time of work in occupational exposure to dusts and irritant gases, reported symptoms, diagnostic tests results and a final diagnosis.

The Regional Bioethical Committee approved the study protocol.

\section{Diagnostic criteria}

Occupational COPD was recognized according to various, applicable during the time of a patient's hospitalization, criteria and lists of occupational diseases (from 1983 [8], 2002 [9] and 2009 [7]) for subjects with:

- Chronic bronchitis induced by toxic substances and/or irritant aerosols, if respiratory insufficiency is diagnosed; and pulmonary emphysema among glassblowers and brass bands musicians, if pulmonary insufficiency is diagnosed - according to the certification criteria of the Regulation of the Council of Ministers from 1983 [8].

- Decreased forced expiratory volume in $1 \mathrm{~s}\left(\mathrm{FEV}_{1}\right)$ less than $50 \%$ of the predicted value due to exposure to irritant dusts, if in the last 10 years of work there had been cases of exceeding respective hygienic norms - according to the certification criteria of the Regulation of the Council of Ministers from 2002 [9].

- Decreased forced expiratory volume in $1 \mathrm{~s}\left(\mathrm{FEV}_{1}\right)$ less than $60 \%$ of the predicted value induced by exposure to dusts and irritant gases, if exceedance of respective hygienic norms was documented within the last 10 years and in at least $30 \%$ of the measurements of occupa- 
tional exposure - according to the certification criteria of the Regulation of the Council of Ministers from 2009 [7].

Individual assessment of the possibility of occupational COPD recognition among patients with non-occupational COPD was performed based on:

- recognition of COPD, in accordance with GOLD guidelines, based on the presence of a post-bronchodilator forced expiratory volume in $1 \mathrm{~s}$ to forced vital capacity ratio $\left(\mathrm{FEV}_{1} / \mathrm{FVC}\right)<0.70$ (irrespective of $\mathrm{FEV}_{1}$ value);

- assessment of the type of occupational exposure based on epidemiological studies, which had identified associations between COPD and a number of occupational exposures, including: mineral dusts, welding fumes, metallic dusts, wood dust, organic dusts (e.g., grain dusts, flour dust) or chemicals;

- duration of occupational exposure longer than 10 years.

The statistical analysis was performed using Statistica 8 . Continuous variables were expressed as mean (M) values \pm standard deviations (SD), while nominal variables were expressed as numbers and percentages.

\section{RESULTS}

Characteristics of the study group, including smoking status is summarized in the Table 1. In the analyzed group of

Table 1. Characteristics of the patients hospitalized due to a suspicion of occupational chronic obstructive pulmonary disease (COPD)

\begin{tabular}{|c|c|c|c|c|}
\hline \multirow[b]{2}{*}{ Variable } & \multicolumn{4}{|c|}{ Respondents } \\
\hline & $\begin{array}{c}\text { total } \\
(\mathrm{N}=150)\end{array}$ & $\begin{array}{c}\text { with occupational } \\
\text { COPD } \\
(\mathrm{N}=19)\end{array}$ & $\begin{array}{c}\text { with non-occupational } \\
\text { COPD } \\
(\mathrm{N}=54)\end{array}$ & $\begin{array}{l}\text { without COPD } \\
\qquad(\mathrm{N}=77)\end{array}$ \\
\hline Age [years] $(\mathrm{M} \pm \mathrm{SD}$ (range) $)$ & $57.4 \pm 7.2(39.0-77.0)$ & $56.1 \pm 7.7(39.0-69.0)$ & $58.6 \pm 6.7(41.0-77.0)$ & $56.9 \pm 7.4(39.0-75.0)$ \\
\hline \multicolumn{5}{|l|}{ Gender $[\mathrm{n}(\%)]$} \\
\hline males & $129(86.0)$ & $18(94.7)$ & $50(92.6)$ & $61(79.2)$ \\
\hline females & $21(14.0)$ & $1(5.3)$ & $4(7.4)$ & $16(20.8)$ \\
\hline $\begin{array}{l}\text { Duration of symptoms [years] } \\
\quad(\mathrm{M} \pm \mathrm{SD} \text { (range) })\end{array}$ & $13.4 \pm 9.4(1.0-40.0)$ & $10.8 \pm 6.5(2.0-24.0)$ & $14.5 \pm 9.9(2.0-40.0)$ & $57.4 \pm 7.2(1.0-38.0)$ \\
\hline $\begin{array}{l}\text { Latency period (duration } \\
\text { of exposure before } \\
\text { the occurrence of symptoms) } \\
\text { [years] }(\mathrm{M} \pm \mathrm{SD} \text { (range) })\end{array}$ & $20.5 \pm 10.8(1.0-42.0)$ & $24.0 \pm 8.8(6.0-40.0)$ & $21.8 \pm 11.5(1.0-40.0)$ & $18.8 \pm 10.6(1.0-42.0)$ \\
\hline \multicolumn{5}{|l|}{ Smoking status $[\mathrm{n}(\%)]$} \\
\hline active smokers & $19(12.7)$ & $2(10.5)$ & $11(20.4)$ & $6(7.8)$ \\
\hline ex-smokers & $67(44.7)$ & $10(52.7)$ & $25(46.3)$ & $32(41.6)$ \\
\hline never smokers & $61(40.7)$ & $7(36.9)$ & $18(33.4)$ & $36(46.8)$ \\
\hline no data & $3(2.0)$ & - & - & - \\
\hline $\begin{array}{l}\text { Duration of smoking [years] } \\
\quad(\mathrm{M} \pm \mathrm{SD} \text { (range) })\end{array}$ & $18.2 \pm 11.0(0.0-44.0)$ & $21.2 \pm 12.4(4.0-44.0)$ & $17.6 \pm 10.5(0.0-40.0)$ & $17.9 \pm 11.2(0.0-40.0)$ \\
\hline
\end{tabular}

M - mean; SD - standard deviation. 
patients, the average duration of work in occupational exposure was $28.5 \pm 10.4$ years (min. 0 years, max 55 years). The analysis of occupational exposure of patients has indicated that in the study population, the biggest groups of people worked in contact with dust containing free crystalline silica $(22 \%)$, metal dusts $(21.3 \%)$ and organic dusts $(19.3 \%$ ) (Table 2). Medium values of pulmonary function tests in the study population and the final diagnosis are shown in the Table 3.

Work-related COPD was diagnosed for 19 (12.7\%) patients; mainly among those with a severe stage of the disease according to GOLD spirometric classification of COPD severity. Fifty-four (36\%) patients fulfilled GOLD criteria although occupational origins of the disease were not recognized. Seventy-seven (51.3\%) patients diagnosed due to a suspicion of work-related COPD did not fulfill the criteria for COPD diagnosis in accordance with GOLD guidelines (Table 3).

Further analyses of the group of 54 (36\%) patients who fulfilled the criteria for COPD diagnosis in accordance with GOLD, in the case of whom occupational origins of the disease were not recognized, have revealed the following: $24.1 \%$ of those patients had not fulfilled spirometric criteria included in the definition of COPD on the Polish list of occupational diseases, 27.8\% had not met the documented exposure to dust or irritant gases criterion and $42.6 \%$ had not fulfilled both of these criteria (Table 4). The detailed analysis of diagnostic test results and individual assessment of occupational exposure have shown that individual assessment of the possibility of COPD development would enable to recognize workrelated COPD in 35 patients (64.8\%) (Table 4).

Table 2. Characteristics of occupational exposure of the patients hospitalized due to a suspicion of occupational chronic obstructive pulmonary disease (COPD)

\begin{tabular}{|c|c|c|c|c|}
\hline \multirow[b]{2}{*}{ Variable } & \multicolumn{4}{|c|}{ Respondents } \\
\hline & $\begin{array}{c}\text { total } \\
(\mathrm{N}=150)\end{array}$ & $\begin{array}{l}\text { with occupational } \\
\text { COPD } \\
(\mathrm{N}=19)\end{array}$ & $\begin{array}{c}\text { with non-occupational } \\
\text { COPD } \\
(\mathrm{N}=54)\end{array}$ & $\begin{array}{l}\text { without COPD } \\
\qquad(\mathrm{N}=77)\end{array}$ \\
\hline $\begin{array}{l}\text { Duration of occupational exposure } \\
\text { to dusts [years] }(\mathrm{M} \pm \mathrm{SD} \text { (range) })\end{array}$ & $28.5 \pm 10.4(0-55)$ & $30.6 \pm 8.9(10-45)$ & $30.2 \pm 11.9(0-55)$ & $26.7 \pm 9.4(4-42)$ \\
\hline \multicolumn{5}{|l|}{ Occupational exposure $[\mathrm{n}(\%)]$} \\
\hline mineral dusts & $33(22.0)$ & $9(47.4)^{*}$ & $9(16.7)$ & $15(19.5)$ \\
\hline metallic dusts & $32(21.3)$ & $6(31.6)$ & $11(20.4)$ & $15(19.5)$ \\
\hline organic dusts & $29(19.3)$ & $2(10.5)$ & $11(20.4)$ & $16(20.8)$ \\
\hline fabric dust & $11(7.3)$ & $0(0.0)$ & $4(7.4)$ & $7(9.1)$ \\
\hline paints & $12(8.0)$ & $0(0.0)$ & $8(14.8)$ & $4(5.2)$ \\
\hline chemicals & $12(8.0)$ & $0(0.0)$ & $4(7.4)$ & $8(10.4)$ \\
\hline wood dust & $5(3.3)$ & $1(5.3)$ & $1(1.9)$ & $3(3.9)$ \\
\hline industrial dust & $6(4.0)$ & $1(5.3)$ & $2(3.7)$ & $3(3.9)$ \\
\hline other & $10(6.7)$ & $0(0.0)$ & $4(7.4)$ & $6(7.8)$ \\
\hline
\end{tabular}

Abbreviations as in Table 1.

$* \mathrm{p} \leq 0.05$. 
Table 3. Pulmonary function tests and the final diagnosis for the patients hospitalized due to a suspicion of occupational chronic obstructive pulmonary disease (COPD)

\begin{tabular}{|c|c|c|c|c|}
\hline \multirow[b]{2}{*}{ Variable } & \multicolumn{4}{|c|}{ Respondents } \\
\hline & $\begin{array}{c}\text { total } \\
(\mathrm{N}=150)\end{array}$ & $\begin{array}{c}\text { with occupational } \\
\text { COPD } \\
(\mathrm{N}=19)\end{array}$ & $\begin{array}{c}\text { with non-occupational } \\
\text { COPD } \\
(\mathrm{N}=54)\end{array}$ & $\begin{array}{l}\text { without COPD } \\
\qquad(\mathrm{N}=77)\end{array}$ \\
\hline $\mathrm{FEV}_{1} \%$ predicted dusts $(\mathrm{M} \pm \mathrm{SD}$ (range) $)$ & $\begin{array}{l}66.7 \pm 24.3 \\
(20.7-124.3)\end{array}$ & $\begin{array}{l}47.9 \pm 19.1 \\
(22.0-85.0)\end{array}$ & $\begin{array}{l}54.5 \pm 18.2 \\
(20.7-104.0)\end{array}$ & $\begin{array}{l}77.8 \pm 22.6 \\
(33.0-124.0)\end{array}$ \\
\hline FVC\% predicted $(\mathrm{M} \pm \mathrm{SD}$ (range) $)$ & $\begin{array}{l}80.1 \pm 19.6 \\
(40.0-133.0)\end{array}$ & $\begin{array}{l}72.1 \pm 21.9 \\
(40.0-133.0)\end{array}$ & $\begin{array}{l}75.5 \pm 19.3 \\
(42.0-126.0)\end{array}$ & $\begin{array}{l}84.1 \pm 18.0 \\
(53.7-129.1)\end{array}$ \\
\hline $\mathrm{FEV}_{1} / \mathrm{FVC}$ predicted $(\mathrm{M} \pm \mathrm{SD}$ (range) $)$ & $\begin{array}{c}66.9 \pm 15.0 \\
(32.3-97.7)\end{array}$ & $\begin{array}{c}52.8 \pm 11.9 \\
(33.0-69.0)\end{array}$ & $\begin{array}{c}57.3 \pm 10.4 \\
(32.3-69.0)\end{array}$ & $\begin{array}{c}75.8 \pm 11.6 \\
(43.0-97.7)\end{array}$ \\
\hline \multicolumn{5}{|l|}{ COPD stage according to GOLD [n $(\%)]$} \\
\hline mild & $17(11.3)$ & $2(10.5)$ & $15(27.8)$ & $0(0.0)$ \\
\hline moderate & $24(16.0)$ & $3(15.8)$ & $21(38.9)$ & $0(0.0)$ \\
\hline severe & $27(18.0)$ & $11(57.9)$ & $16(29.6)$ & $0(0.0)$ \\
\hline very severe & $5(3.3)$ & $3(15.8)$ & $3(5.6)$ & $0(0.0)$ \\
\hline \multicolumn{5}{|l|}{$\begin{array}{l}\text { COPD investigated according to legal } \\
\text { regulations regarding occupational } \\
\text { diseases }[\mathrm{n}(\%)]\end{array}$} \\
\hline from 2009 [7] & $83(53.3)$ & $2(2.4)$ & $44(81.5)$ & $46(59.7)$ \\
\hline from $2002[9]$ & $42(33.9)$ & $5(27.8)$ & $9(24.3)$ & $28(40.6)$ \\
\hline from $1983[8]$ & $25(20.2)$ & $12(66.7)$ & $1(2.7)$ & $12(17.4)$ \\
\hline
\end{tabular}

$\mathrm{FEV}_{1}$ - forced expiratory volume in the first second; $\mathrm{FVC}$ - forced vital capacity; $\mathrm{FEV}_{1} / \mathrm{FVC}$ - ratio of forced expiratory volume in the first second to forced vital capacity; COPD - chronic obstructive pulmonary disease; GOLD - Global Initiative for Chronic Obstructive Lung Disease.

Table 4. Individual assessment of the possibility of occupational chronic obstructive pulmonary disease (COPD) recognition among the patients with non-occupational COPD, hospitalized due to a suspicion of COPD

\begin{tabular}{lccc}
\hline & \multicolumn{2}{c}{$\begin{array}{c}\text { Respondents with non-occupational COPD } \\
\text { Cause of not recognizing } \\
\text { occupational COPD } \\
\text { and criteria assessment }\end{array}$} & \multicolumn{3}{c}{$\begin{array}{c}(\mathrm{N}=54) \\
\text { according to legal regulations } \\
\text { regarding occupational diseases }\end{array}$} \\
\cline { 2 - 4 } & $\begin{array}{c}\text { regulations } \\
\text { from 2009 [7] } \\
(\mathrm{N}=44)\end{array}$ & $\begin{array}{c}\text { regulations } \\
\text { from 2002 [9] } \\
(\mathrm{N}=9)\end{array}$ & $\begin{array}{c}\text { regulations } \\
\text { from } 1983[8] \\
(\mathrm{N}=1)\end{array}$ \\
\hline $\begin{array}{l}\text { Unfulfilled spirometric criteria [n] } \\
\text { legal regulations } \\
\text { individual assessment }\end{array}$ & 9 & 4 & n.a. \\
$\begin{array}{l}\text { Unfulfilled hygienic criteria [n] } \\
\text { legal regulations } \\
\text { individual assessment }\end{array}$ & 0 & 4 & - \\
\hline
\end{tabular}


Table 4. Individual assessment of the possibility of occupational chronic obstructive pulmonary disease (COPD) recognition among the patients with non-occupational COPD, hospitalized due to a suspicion of COPD - cont.

\begin{tabular}{|c|c|c|c|}
\hline \multirow{2}{*}{$\begin{array}{l}\text { Cause of not recognizing } \\
\text { occupational COPD } \\
\text { and criteria assessment }\end{array}$} & \multicolumn{3}{|c|}{$\begin{array}{l}\text { Respondents with non-occupational COPD } \\
\qquad(\mathrm{N}=54) \\
\text { according to legal regulations } \\
\text { regarding occupational diseases }\end{array}$} \\
\hline & $\begin{array}{l}\text { regulations } \\
\text { from } 2009[7] \\
\quad(\mathrm{N}=44)\end{array}$ & $\begin{array}{l}\text { regulations } \\
\text { from } 2002[9] \\
\quad(\mathrm{N}=9)\end{array}$ & $\begin{array}{l}\text { regulations } \\
\text { from } 1983[8] \\
\quad(\mathrm{N}=1)\end{array}$ \\
\hline \multicolumn{4}{|c|}{ Unfulfilled both spirometric and hygienic criteria [n] } \\
\hline legal regulations & 21 & 2 & n.a. \\
\hline individual assessment & 8 & 2 & - \\
\hline \multicolumn{4}{|l|}{ Lack of respiratory failure $[\mathrm{n}]$} \\
\hline legal regulations & n.a. & n.a. & 1 \\
\hline individual assessment & - & - & 1 \\
\hline $\begin{array}{l}\text { Individual assessment of the possibility } \\
\text { of occupational COPD recognition }[\mathrm{n}(\%)]\end{array}$ & $29(65.9)$ & $6(66.6)$ & $0(0.0)$ \\
\hline
\end{tabular}

n.a. - not applicable.

\section{DISCUSSION}

In Poland, as compared to the previous years, the number of cases of work-related chronic obstructive pulmonary disease has significantly decreased over the recent years [10]. At the same time the incidence of this disease in Poland and worldwide is constantly increasing. Chronic obstructive pulmonary disease was ranked as the fourth cause of deaths in the world in 2004, and in 2030 it is believed that it will have become the third cause of death [1]. It is estimated that about $15 \%$ of COPD could be attributable to workplace exposure [6]. Organic and inorganic particles, fumes or irritant gases may cause COPD even at prevailing levels of exposure [11-17].

Würtz et al. in a Danish population-based cohort, have found more than a threefold increase risk for occupational exposure to vapor, gas, dust and fumes (predominantly organic dust) in this never-smoking population, with a corresponding 48\% (95\% confidence interval (CI): 30-65) population attributable fraction among never-smokers [18]. Stoleski et al. conducted a cross-sectional study with 75 male dairy farmers exposed to dusts in the workplace and compared them with an equivalent number of male office workers similar in age, and duration of employment. That study results have shown that farmers had significantly higher COPD prevalence than office controls $(10.7 \%$ vs. $2.7 \%$, $\mathrm{p}=0.049)$ [19].

Clinical observations and data from literature have led us to an assumption that cases of occupational COPD might have been under reported and thus, the current number of work related COPD is greatly underestimated. What is more, the same has been suggested by other authors [20]. This may also result from certification criteria currently applicable in Poland.

In this study we have analyzed the causes of the low prevalence of work-related COPD in the context of the existing certification criteria. We conducted an analysis of medical documentation of patients with a suspicion of workrelated COPD with particular emphasis on the type of occupational exposure, duration of occupational exposure, reported symptoms, diagnostic tests results and final diag- 
nosis. The analyzed medical documentation was discussed according to various, applying to the time of a patient's hospitalization, criteria and lists of occupational diseases (from 1983, 2002 and 2009).

The Annex to the Regulation of the Council of Ministers of November 18, 1983 on occupational diseases [8] contained a list of 20 types of occupational diseases that might be work-related. On the list there was no concept of chronic obstructive pulmonary disease itself, however, the list contained 2 other diseases that COPD consists of, i.e., chronic bronchitis induced by toxic substances, irritant aerosols in the case of respiratory insufficiency (in point 4) and pulmonary emphysema in the case of pulmonary insufficiency among glassblowers and brass bands musicians (in point 5). The document was valid in Poland between December 6, 1983 and September 3, 2002 [8].

In the light of development of medical knowledge, as well as the need to update Polish law in compliance with the European Union (EU) directives of July 30, 2002, a new Regulation of the Council of Ministers on occupational diseases, detailed procedures of reporting suspected cases, recognition and diagnosis of occupational diseases was introduced [9]. The annex to this regulation contained a list of occupational diseases, including, in point 5: "chronic obstructive bronchitis, resulting in permanent impairment of lung ventilation with a decreased forced expiratory volume in $1 \mathrm{~s}\left(\mathrm{FEV}_{1}\right)$ less than $50 \%$ of the predicted value due to exposure to irritant dusts, if in the last 10 years of work respective hygienic norms were exceeded." It also determined the period of time during which documented evidence of COPD symptoms entitled to certify an occupational disease, despite earlier termination of occupational exposure (1 year). The requirement for exceedance of the respective hygienic norms and the time of their occurrence was tightened [9].

In the currently applicable Regulation of the Council of Ministers of June 30, 2009 on occupational diseases [7], chronic obstructive pulmonary disease is included in point 5 of the list of occupational diseases as: chronic obstructive bronchitis resulting in a permanent impairment of lung ventilation with a decreased expiratory volume in $1 \mathrm{~s}\left(\mathrm{FEV}_{1}\right)$ less than $60 \%$ of the predicted value induced by exposure to dusts and irritant gases, if exceedance of the respective hygienic norms is documented within the last 10 years and in at least $30 \%$ of the measurements of occupational exposure. The period of time during which documented evidence of COPD symptoms entitles to certify an occupational disease, despite earlier termination of occupational exposure, is 1 year. Definition of COPD on the list of occupational diseases is described in detail and it includes both spirometric and hygienic criteria, which allow to consider occupational etiology of the disease [7].

The analysis of the study results has revealed that COPD in our country is rarely recognized as an occupational disease, and that it had been diagnosed only for 19 patients hospitalized with a suspicion of work-related COPD in Department of Occupational Diseases and Environmental Health, Nofer Institute of Occupational Medicine, Łódź, Poland, between 1998 and 2015. Similarly, Lee et al. by means of an analysis of data from the Occupational Safety and Health Research Institute of the Korea Occupational Safety and Health Agency from 1998 to 2007, have revealed that only 4 out of 13 cases of occupational COPD had been approved in terms of their work relatedness [21,22]. In Great Britain there were 85 cases in 2014 as compared with 85 in 2013, and an annual average of around 160 over the period 2003-2014. There were approximately 5 new cases of emphysema due to cadmium poisoning in the period between 2003 and 2014 within the Industrial Injuries and Disablement Benefit (IIDB) scheme [23].

Moreover, the study results also indicate that occupational COPD is recognized in our country mainly among the patients with a severe stage of the disease according to GOLD criteria, who work in occupational exposure for a long period of time - average: $30.2 \pm 11.9$ years. In Poland, there is no definite criterion of length of occupational exposure. 
However, in other countries, this aspect has been taken into account in medical certification process - e.g., in Great Britain, coal workers with at least 20 years of underground exposure have been eligible for compensation under the Department for Work and Pensions IIDB scheme since 1993 [23].

We have also analyzed the group of $54(36 \%)$ patients who had fulfilled GOLD criteria for COPD diagnosis in the case of whom occupational origins of the disease had not been recognized due to the existing criteria, and we have found that in Poland, clinical evaluation together with hygienic assessment result in limitations in recognition of occupational COPD. Furthermore, the strict hygienic criterion excludes recognition of COPD for the patients exposed in their workplace for a long period of time to dusts, vapor, fumes and irritant gases if the work environment monitoring had not been performed (e.g., farmers).

Consequently, we have evaluated those patients individually, based on the review of literature, because most of the evidence of an association between exposures to dust, vapor, fumes and irritant gases at work and COPD development is available from the studies on groups of workers with specific professions and/or exposures. We have considered various aspects of work, including the type and duration of occupational exposure.

The review of the literature has indicated that the impact of workplace exposure on the COPD development has been noticed for many different occupational exposures [24-27]. Sunyer et al. have found that occupational exposure to high levels of biological dust among young adults is connected with chronic bronchitis and pulmonary ventilatory defects, independently of asthma and smoking [24]. Also occupational exposure to organic dusts for farmers has been defined as a causative factor for COPD development [11].

Other studies have demonstrated accelerated annual decrements in $\mathrm{FEV}_{1}$ independent of smoking for employees exposed to red cedar or other wood dusts [17,25]. Hniz- do et al. have shown that employees who had worked in exposure to crystalline silica also had had an increased risk of airflow obstruction independent of radiological silicosis [26]. Furthermore, exposure to coal dust for coal miners [12], grain dusts for grain elevator workers [13], gases and fumes for welders [14], industrial dusts for construction workers [15] and cotton dusts for cotton textile workers [16] has been indicated as risk factors for COPD. It needs to be highlighted that in the analyzed group most of the patients had worked in such types of occupational exposure as those mentioned above.

Many previous studies had analyzed the relationship between occupational exposure duration and COPD. Therefore, in individual assessment of the possibility of occupational COPD development we have also considered this aspect of occupational exposure, especially that in our analyzed group it is particularly high $-30.2 \pm 11.9$ years. Stoleski et al. have shown that dairy farmers had had a significant association between COPD and employment duration of over 20 years [19]. While Norwegian tunnel workers exposed for more than 10 years had had significantly more subjects with $\mathrm{FEV}_{1} / \mathrm{FVC}<0.7$ than those exposed for fewer years [27].

Similarly, in Shamssain's study the proportion of men with an $\mathrm{FEV}_{1} / \mathrm{FVC}$ below $70 \%$ was higher not only for the exposed workers in comparison with the control subjects but also higher for the exposed workers with more years of employment (among the subjects employed and exposed for 10 years as compared with the workers employed and exposed for a shorter period of time) [28]. In an Italian study, a significant increase in COPD for each year of exposure has been noticed for farmers, welders, painters and textile workers, and the lowest exposure time included in the study had been 9 years [29].

Our analysis has indicated that there is the need to propose new criteria for occupational COPD diagnosis in Poland. Assessment of the possibility of occupational COPD recognition based on GOLD guidelines, the 
type and duration of occupational exposure would allow for recognition of occupational COPD for more patients with COPD (64.8\%) exposed for a long period of time to dusts, vapor, fumes and irritant gases at work. That would cause a reduction in the significant discrepancy between the estimated prevalence of occupational COPD in Poland and the current trends.

We realize that there is a number of difficulties surrounding the ability to determine the effect of workplace exposures on COPD development, and that in some cases medical certification process based on individual analysis of each case may be problematic and more complicated, e.g., in the cases of former or active smokers with COPD. However, this aspect should be also considered because COPD is common among the general population and tobacco smoke is indicated as the most significant risk factor for COPD development [1]. On the other hand, never-smokers constitute a considerable part of those suffering from COPD. Lamprecht et al. [3] have indicated that $27.7 \%$ of the people who suffered from COPD had never smoked, and in those cases other risk factors for the disease development, including occupational ones, play an important role. Marine et al., in the study of 3400 miners over a 10-year period, assessed an independent contribution of smoking and exposure to respirable dust to clinically significant measures of respiratory dysfunction. The authors have found that an exposure-related $\mathrm{FEV}_{1}$ reduction for coal miners seem to be irrespective of the smoking history [12].

What is more, Blanc et al. have shown that joint exposure to both: smoking as well as occupational factors markedly increase the risk of COPD (odds ratio $(\mathrm{OR})=$ 14.1, 95\% CI: 9.33-21.2) [30]. Trupin et al. have demonstrated that past occupational exposures increase the likelihood of COPD significantly, independent of the effects of tobacco smoke [31]. These reports indicate a more than additive effect of concurrent exposure to tobacco smoke and exposure to dust, vapor, fumes and gases in the work- place. Working in a major, long-term exposure to dust, vapor, gases should be considered as an independent risk factor for COPD development and should not be ignored, despite smoking, especially among workers employed for a long period of time in the workplaces where hygienic standards are exceeded. Therefore, in Poland, smoking habit does not disqualify the possibility of recognition of an occupational disease.

We can conclude that in our country, both clinical and hygienic criteria cause limitations in recognition of occupational COPD. There is the need to propose new criteria for diagnosis of occupational COPD in Poland. We realize that none of the previous as well as the current criteria for recognition of occupational COPD are not perfect.

What is more, data from other countries also indicates that establishment of criteria for occupational COPD is difficult. In Korea, specific criteria for occupational COPD recognition are limited to workers exposed to high concentrations of coal mine dust, silica, or cadmium fumes for prolonged periods [21]. While, in the United Kingdom (UK) occupational origin of disease is recognized for workers exposed to coal dust and in the case of emphysema-inhalation of cadmium fumes for a period of, or periods which amount in aggregate to, 20 years or more [32]. In the UK for example, nowadays, prescription for other occupational groups including cotton textile workers, welders, grain workers and workers exposed to silica or isocyanates is also considered [32].

However, there has been a lack of suitable evidence to recommend prescription or amendment to prescription for those occupational categories [32]. Researchers will continue additional study to analyze the relationship of lung function decrements in COPD to levels of exposure from specific agents for various occupational categories. The results of further studies may be used for formulating detailed criteria for recognition of occupational COPD. In Germany chronic obstructive bronchitis or emphysema may be recognized as an occupational diseases and is 
contained in the annex to the German ordinance on occupational diseases (point 4.1.11) as chronic obstructive bronchitis or emphysema for underground hard coal miners if there is evidence of exposure to a cumulative dose of generally 100 fine dust years $\left(\mathrm{mg} / \mathrm{m}^{3} \times\right.$ years) [33].

Similarly, in the European Commission document "Information notices on occupational diseases: a guide to diagnosis" chronic obstructive bronchitis or emphysema in the case of miners working in underground coal mines may be recognized as an occupational disease according to the following criteria: confirmation of occupational exposure underground in a hard coal mine, if possible assessment by history and working conditions shows significant levels of respirable and inhalable dust, totaling approx. $100 \mathrm{mg} / \mathrm{m}^{3}$ xyear or more. What is more, minimum duration of exposure has been established for 5 years. However, maximum latent period cannot be fixed, the occurrence of disease being a function of the cumulative dose [34].

According to the new statement of Collegium Ramazzini on Chronic Obstructive Pulmonary Disease [35], disease may be substantially controlled by the international community adopting the 6 action items: preventing smoking, occupational exposures, environmental exposures, expanding medical surveillance, conducting research and recognizing and compensating COPD as an occupational disease. For preventing occupational exposures the global community of occupational safety and health professionals should, e.g., raise awareness about the magnitude of occupational COPD and its causes among stakeholders: workers, employers, insurance companies and social insurance agencies through a social marketing campaign. Identification of major tasks contributing to vapor, gases, dusts, or fumes (VGDF) exposure in specific occupational sectors, with a focus on agriculture, construction, mining, transportation and manufacturing is also important. The process should include focus groups and other input from stakeholders [35].

There is the need to establish international guidelines for the recognition of COPD as a compensable disease for persons who have worked in an occupation with sufficient VDGF exposures to cause this disorder [35].

\section{CONCLUSIONS}

In Poland, COPD is rarely recognized as an occupational disease, mainly due to the existing criteria - both clinical and hygienic ones.

Occupational COPD is recognized in Poland mostly among the patients with a severe stage of the disease according to GOLD spirometric classification of COPD severity.

There is the need to propose new criteria of occupational COPD diagnosis in Poland.

\section{REFERENCES}

1. Global Initative for Chronic Obstructive Lung Disease. Global strategy for the diagnosis and management, and prevention of chronic obstructive pulmonary disease [Internet]. Fontana: The Initative; 2016 [cited 2016 Oct 26]. Available from: http://www.paramounthealthcare.com/documents/clinicalpractice-guidelines/2016-GOLD-Pocket-Guide.pdf.

2. Bednarek M, Maciejewski J, Wozniak M, Kuca P, Zielinski J. Prevalence, severity and underdiagnosis of COPD in the primary care setting. Thorax. 2008;63:402-7, https://doi. org/10.1136/thx.2007.085456.

3. Lamprecht B, McBurnie M, Vollmer W, Gudmundsson G, Welte T, Nizankowska-Mogilnicka E, et al. COPD in never smokers: Results from the population-based burden of obstructive lung disease study Chest. 2011;139:752-63, https://doi.org/10.1378/chest.10-1253.

4. Blanc PD, Toren K. Occupation in chronic obstructive pulmonary disease and chronic bronchitis: An update. Int J Tuberc Lung Dis. 2007;11:251-7.

5. Boggia B, Farinaro E, Grieco L, Lucariello A, Carbone U. Burden of smoking and occupational exposure on etiology of chronic obstructive pulmonary disease in workers of southern Italy. J Occup Environ Med. 2008;50:366-70, https://doi. org/10.1097/JOM.0b013e318162f601. 
6. Balmes J, Becklake M, Blanc P, Henneberger P, Kreiss K, Mapp C, et al. American Thoracic Society statement: Occupational contribution to the burden of airway disease. Am J Respir Crit Care Med. 2003;167:787-97, https://doi. org/10.1164/rccm.167.5.787.

7. [Regulation of the Council of Ministers of June 30, 2009 on occupational diseases. Off J Law 2009, No. 105, item 869]. Polish.

8. [Regulation of the Council of Ministers of November 18, 1983 on occupational diseases. Off J Law 1983, No. 65, item 294]. Polish.

9. [Regulation of the Council of Ministers of July 30, 2002 on occupational diseases. Off J Law 2002, No. 132, item 1115]. Polish.

10. Szeszenia-Dąbrowska N, Wilczyńska U, Sobala W. [Occupational diseases in Poland in 2015]. Lódź: Institute of Occupational Medicine; 2015. Polish.

11. Monso E, Riu E, Radon K, Magarolas R, Danuser B, Iversen $\mathrm{M}$, et al. Chronic obstructive pulmonary disease in neversmoking animal farmers working inside confinement buildings. Am J Ind Med. 2005;46:357-62, https://doi.org/10.1002/ ajim.20077.

12. Marine W, Gurr D, Jacobsen M. Clinically important respiratory effects of dust exposure and smoking in British coal miners. Am Rev Respir Dis. 1988;137:106-12, https:/doi. org/10.1164/ajrccm/137.1.106.

13. Kennedy S, Dimich-Ward H, Desjardins A, Kassam A, Vedal S, Chan-Yeung M. Respiratory health among retired grain elevator workers. Am J Respir Crit Care Med. 1994; 150:59-65, https://doi.org/10.1164/ajrccm.150.1.8025773.

14. Hayden S, Pincock A, Hayden J, Tyler L, Cross K, Bishop J. Respiratory symptoms and pulmonary function of welders in the engineering industry. Thorax. 1984;39:442-7, https:// doi.org/10.1136/thx.39.6.442.

15. Bakke B, Ulvestad B, Stewart P, Eduard W. Cumulative exposure to dust and gases as determinants of lung function decline in tunnel construction workers. Occup Environ Med. 2004;61:262-9, https://doi.org/10.1136/oem.2003.008409.
16. Shi J, Mehta A, Hang J, Zhang H, Dai H, Su L, et al. Chronic lung function decline in cotton textile workers: Roles of historical and recent exposures to endotoxin. Environ Health Perspect. 2010;118:1620-4, https://doi.org/10.1289/ ehp.0901178.

17. Jacobsen G, Schlünssen V, Schaumburg I, Sigsgaard T. Increased incidence of respiratory symptoms among female woodworkers exposed to dry wood. Eur Respir J. 2009; 33:1268-76, https://doi.org/10.1183/09031936.00048208.

18. Würtz ET, Schlünssen V, Malling TH, Hansen JG, Omland $\varnothing$. Occupational COPD among Danish never-smokers: A population-based study. Occup Environ Med. 2015;72: 456-9, https://doi.org/10.1136/oemed-2014-102589.

19. Stoleski S, Minov J, Karadzinska-Bislimovska J, Mijakoski D. Chronic obstructive pulmonary disease in neversmoking dairy farmers. Open Respir Med J. 2015;9:59-66, https://doi.org/10.2174/1874306401509010059.

20. Cho Y, Lee J, Choi M, Choi W, Myong JP, Kim HR, et al. Work-related COPD after years of occupational exposure. Ann Occup Environ Med. 2015;27:6, https://doi.org/10.1186/ s40557-015-0056-1.

21. Park SY, Kim HR, Song J. Workers' compensation for occupational respiratory diseases. J Korean Med Sci. 2014;29 Suppl:S47-51, https://doi.org/10.3346/jkms.2014.29.S.S47.

22. Lee HP, Koh DH, Lee EC. Occupational chronic obstructive pulmonary disease cases evaluated by workers' compensation in Korea. Korean J Occup Environ Med. 2009; 21:53-62.

23. Health and Safety Executive. Work-related Chronic Obstructive Pulmonary Disease (COPD) in Great Britain in 2014 [Internet]. London: The Executive; 2016 [cited 2016 Oct 26]. Available from: http://www.hse.gov.uk/statistics/ causdis/copd/copd.pdf.

24. Sunyer J, Kogevinas M, Kromhout H, Antó JM, Roca J, Tobias A, et al. Pulmonary ventilatory defects and occupational exposures in a population-based study in Spain. Am J Respir Crit Care Med. 1998;157:512-7, https://doi.org/ 10.1164/ajrccm.157.2.9705029. 
25. Noertjojo HK, Dimich-Ward H, Peelen S, Dittrick M, Kennedy SM, Chan Yeung M. Western red cedar dust exposure and lung function: A dose-response relationship. Am J Respir Crit Care Med. 1996;154:968-73, https://doi. org/10.1164/ajrccm.154.4.8887593.

26. Hnizdo E, Vallyathan V. Chronic obstructive pulmonary disease due to occupational exposure to silica dust: A review of epidemiological and pathological evidence. Occup Environ Med. 2003;60:237-43, https://doi.org/10.1136/oem.60.4.237.

27. Ulvestad B, Bakke B, Melbostad E, Fuglerud P, Kongerud J, Lund MB. Increased risk of obstructive pulmonary disease in tunnel workers. Thorax. 2000;55:277-82, https:// doi.org/10.1136/thorax.55.4.277.

28. Shamssain MH. Pulmonary function and symptoms in workers exposed to wood dust. Thorax. 1992;47:84-7, https://doi. org/10.1136/thx.47.2.84.

29. Mastrangelo G, Tartari M, Fedeli U, Fadda E, Saia B. Ascertaining the risk of chronic obstructive pulmonary disease in relation to occupation using a case-control design. Occup Med. 2003;53:165-72, https://doi.org/10.1093/occmed/ kqg041.

30. Blanc PD, Iribarren C, Trupin L, Earnest G, Katz PP, Balmes J, et al. Occupational exposures and the risk of COPD: Dustytrades revisited. Thorax. 2009;64:6-12.
31. Trupin L, Earnest G, San Pedro M, Balmes JR, Eisner MD, Yelin E, et al. The occupational burden of chronic obstructive pulmonary disease. Eur Respir J. 2003;22:462-9, https://doi.org/10.1183/09031936.03.00094203.

32. Industrial Injuries Advisory Council, Department for Work and Pensions. Chronic Obstructive Pulmonary Disease (COPD) - Chronic bronchitis and emphysema [Internet]. Norwich: The Council; 2007 [cited 2014 Jul 14]. Available from: http://iiac.independent.gov.uk/pdf/reports/Cm7253.pdf.

33. Deutsche Gesetzliche Unfallversicherung. DGUV statistics 2013. Figures and long-term trends [Internet]. Berlin: Deutsche Gesetzliche Unfallversicherung; 2013 [cited 2016 Oct 26]. Available from: http://www.dguv.de/medien/inhalt/ zahlen/documents/schueler/dguvstatistiken2013e.pdf.

34. EU Law and Publications [Internet]. Luxembourg: The Publications; 2017 [cited 2016 Oct 26]. Information notices on occupational diseases: A guide to diagnosis. Available from: http://bookshop.europa.eu/uri?target=EUB:NOTIC E:KE8009534:EN:HTML.

35. Collegium Ramazzini [Internet]. Bentivoglio: The Collegium; 2017 [cited 2016 Oct 26]. Collegium Ramazzini Statements. A new approach to the control of Chronic Obstructive Pulmonary Disease (COPD). Available from: http:// www.collegiumramazzini.org/publications.asp.

This work is available in Open Access model and licensed under a Creative Commons Attribution-NonCommercial 3.0 Poland License - http://creativecommons.org/ licenses/by-nc/3.0/pl/deed.en. 